\title{
LOS ACTOS SILENCIOSOS EN LA CONVERSACIÓN DE LOS JÓVENES ESPAÑOLES: ¿(DES)CORTESÍA O “ANTICORTESÍA”?
}

\author{
LAura CAmargo Fernández y BeAtriz MÉndeZ Guerrero \\ Universitat de les Illes Balears \\ laura.camargo@uib.es - beatriz.mendez@uib.es
}

\begin{abstract}
Resumen
El silencio es un elemento tan complejo y diverso como habitual en la comunicación humana, por lo que debe ser atendido en la investigación pragmática. Para ello, ha de conocerse qué lo motiva y qué funciones cumple en la interacción conversacional. Los estudios sobre cortesía verbal aportan referencias esenciales sobre el fenómeno silencioso asociándolo a la descortesía (Leech, 1983; Brown y Levinson, 1987; Jaworski, 1997; Haverkate, 1994; Sifianou, 1997). Asimismo se ha considerado el silencio como un componente cultural que puede ser interpretado de manera positiva o negativa pero jamás como un elemento vacío (Cestero, 1999; Nakane, 2007).

En este trabajo se mostrará que muchos silencios propios de la conversación en español no constituyen actos que dañen la imagen del interlocutor, sino que son simples estrategias comunicativas intencionales que pueden, en algunos contextos, relacionarse con la anticortesía (Zimmermann, 2003). Para demostrarlo, se presentará: 1) una taxonomía de las funciones pragmáticas del silencio en la conversación informal en español; 2) una escala de (des)cortesía a partir de aspectos como las duración del silencio y el coste/beneficio que tiene este para hablante y destinatario; y 3) la relación entre silencio y "anticortesía”.
\end{abstract}

PALABRAS CLAVE: Silencio, Pragmática, (Des)cortesía, Anticortesía, Conversación espontánea.

\begin{abstract}
As a complex, diverse but also very common element in human communication, silence needs to be investigated by Pragmatics. In order to understand the phenomenon, we have to know what motivates silence and what functions it accomplishes during conversational interaction. The studies in Politeness have provided essential references on the silent phenomenon, often associating it to impoliteness (Leech, 1983; Brown y Levinson, 1987; Jaworski, 1997; Haverkate, 1994; Sifianou, 1997). Silence is also regarded as a cultural component that can be interpreted in a positive or negative way, but never as an empty element (Cestero, 1999; Nakane, 2007).

In this paper it will be shown that many silences in Spanish conversation are not Face Threatening Acts, but elements acting as intentional communication strategies that might, in some contexts, interact with Anti politeness (Zimmermann, 2003). To demonstrate this thesis, we will present: 1) a pragmatic taxonomy of silence's functions in Spanish informal conversation; 2) a scale of impoliteness including aspects such as the duration of silence and the cost/benefit both for speaker and addressee; and 3) the relationship between silence and Anti politeness.
\end{abstract}

KEY WORDS: Pragmatics, Impoliteness, Anti politeness, Spontaneous conversation. 


\section{Introducción}

El silencio es concebido en gran parte de la cultura occidental, principalmente en las sociedades orientadas hacia la cortesía positiva, como una prueba de falta de cooperación lingüística; por tanto en estas culturas ha sido habitualmente interpretado negativamente como un acto de descortesía. Sin embargo, recientes estudios (Camargo y Méndez, en prensa) indican que hay que mostrar cautela al asignar grados de (des)cortesía al silencio, ya que estos dependerán en gran medida del contexto en el que se produzca el acto silencioso.

Numerosos autores (Leech, 1983; Brown y Lenvison, 1987; Jaworski, 1993; Haverkate, 1994; Sifianou, 1997) han abordado el estudio de los actos silenciosos desde un enfoque sociopragmático llevados por la necesidad de proporcionar apuntes sobre los comportamientos (des)corteses de los individuos y sobre el papel del silencio en ellos. De manera general, los estudios sobre cortesía verbal tratan de explicar el comportamiento de los individuos en la interacción conversacional y la manera en que este se evalúa. El interés radica en que ni las personas se han conducido siempre de igual modo, ni lo hacen de forma homogénea en las distintas culturas $y$, aunque la variedad ha existido siempre, este tiempo de cercanías globales ha contribuido a hacerla patente y a requerir alguna explicación a nuestros aciertos y desaciertos comunicativos cotidianos, para así facilitar los cada vez más frecuentes intercambios interculturales. Por todo ello, en primer lugar, han de conocerse las causas que motivan el silencio y las funciones que cumple en la conversación.

Es sabido que el modo en que nos dirigimos a una persona depende no solo de nuestra intención comunicativa, sino también de otros factores como el grado de confianza, las diferencias de edad, de jerarquía, el sexo de los hablantes, etc. En otras palabras, entre hablante y oyente existe una relación social que se organiza en torno a dos ejes básicos: un eje horizontal, determinado por el grado de conocimiento previo, de confianza y proximidad, que da lugar a relaciones en un plano de igualdad; y un eje vertical que establece diferencias de jerarquía basadas en la edad, el estatus, los conocimientos adquiridos, etc. (Kerbrat-Orecchioni, 1992: 74). Los estudios sobre la cortesía verbal se ubican en la pragmática precisamente por ser esta la perspectiva lingüística que se ocupa del lenguaje en su contexto de uso y aunque no todos los estudios sigan esta línea "la pragmática $[\ldots]$ no debería prescindir de ejemplos basados en intercambios comunicativos reales" (Camargo, 2006: 83). En este trabajo seguimos la propuesta de Bravo (2003, $2004,2010)$ de hablar de pragmática sociocultural para los trabajos sobre cortesía verbal, pues enfatiza su carácter eminentemente social y contextual. La autora confiere un lugar central al concepto de imagen social (face). Al no considerar los aspectos positivo y 
negativo -propuestos por Brown y Levinson (1987) y que serán vistos más adelante-, presenta los conceptos de autonomía y afiliación. El primero se refiere a la percepción que tiene un individuo de sí mismo y que los demás tienen de él como alguien con entidad propia en el grupo, mientras que el segundo "agrupa aquellos comportamientos en los cuales se refleja cómo una persona desea verse y ser vista por los demás en cuanto a aquellas características que la identifican con el grupo" (Bravo, 2003: 106).

Ciertamente, en los intercambios comunicativos, estos dos parámetros (autonomía y afiliación) están expuestos continuamente al devenir conversacional, pudiendo a lo largo de la misma realizarse actos que los amenacen. En este marco de potenciales amenazas a la imagen es donde, según Brown y Levinson (1987: 65), actúa la cortesía, promoviendo estrategias comunicativas para evitar o minimizar la amenaza a la imagen social.

Partiendo de estas consideraciones, en este estudio presentaremos: 1) algunas de las funciones más representativas del silencio en la conversación en español; 2) una taxonomía pragmática basada en los 1825 actos silenciosos recogidos en un corpus de conversaciones espontáneas de 15 horas de duración entre 10 informantes jóvenes (5 mujeres y 5 hombres); 3) una escala de (des)cortesía a partir de aspectos como la duración y el coste-beneficio para los hablantes; y 4) la relación existente el silencio y la anticortesía.

\section{Hacia una taxonomía pragmática del silencio}

Como se ha dicho, los silencios son fenómenos altamente culturales y pueden ser interpretados de forma positiva o negativa, pero jamás como elementos vacíos. Por ello, abogamos por acometer su estudio desde la pragmática y por abandonar el estereotipo del silencio como fenómeno imposible de abordar desde una óptica lingüística. Los estudios que se han realizado hasta el momento sobre paralenguaje y pragmática intercultural han concluido que la española es una cultura poco propicia al silencio en la que hay una clara preponderancia de la palabra y en la que el silencio puede interpretarse como un elemento "molesto" (Haverkate, 1994: 58). Pero eso no significa que el silencio no aparezca en nuestro discurso y mucho menos que no tenga que ser estudiado.

Entendemos por silencio (Camargo y Méndez, en prensa) "la ausencia de habla superior a un segundo que se utiliza para comunicar; es, por tanto, una estrategia paralingüística relevante que trasmite información, estructura la conversación o expresa emo- 
ciones y que está claramente determinada por factores contextuales, sociales y culturales". De este modo, dichos actos comunicativos son omisiones de habla intencionales ${ }^{1}$ que a menudo se realizan de manera voluntaria y otras veces de forma inconsciente y que pueden ser más significativas que la propia palabra. Esto último se desprende de la idea de Searle (2001: 274) que explica que "no todos los estados conscientes son intencionales, ni todos los estados intencionales son conscientes". En consecuencia, los silencios en la interacción serán, como decimos, siempre intencionales pero no serán necesariamente conscientes. Frente a estos signos comunicativos se hallaría el mutismo (Jaworski, 1993; Kurzon, 1997) o quietud (Poyatos, 1994), que es la ausencia de habla que no comunica, aquí entendida como "no conversacional". Estos últimos elementos no formarán parte de nuestro análisis. Tampoco serán abordadas aquí las pausas, ausencias de habla con un periodo de tiempo comprendido entre 0 y 1 segundos (Cestero, 1999: $35)^{\prime 2}$.

El uso del silencio - que no debe confundirse, como ya se ha dicho, con el mutismo o la quietud-casi siempre lleva implícita la intención de callar, la de no decir algo y, de esta forma, puede ser también un medio indirecto para conseguir determinados objetivos (Escandell, 2006: 37). Por consiguiente, comunicar implicará siempre una actividad de interpretación constante apoyada, entre otros elementos, por valores socioculturales. Este proceso de interpretación se volverá más relevante, si cabe, en el caso del silencio para el que necesitamos, en la mayoría de ocasiones, del conocimiento de unos parámetros socioculturales compartidos (Vivas, 2011: 26). Podemos decir, por tanto, que el silencio es un elemento altamente contexto-dependiente ${ }^{3}$.

\footnotetext{
${ }^{1}$ Entiéndase que el silencio, cuando aparece en la interacción, no puede considerarse nunca un elemento vacío (esto es, no puede ser mutismo). En palabras de Mateu (2001: 274): “[en la conversación] el silencio absoluto, asignificativo, no existe, pues indicaría vacuidad total, incomunicación, y ello entraría en contradicción con uno de los principios básicos de la Teoría de la Comunicación. Como defiende la Escuela de Comunicación de Palo Alto: no es posible no comunicar". De modo que en este trabajo se entenderán como significativos todos los silencios presentes en la conversación.

${ }^{2}$ Ya advertimos de que en este trabajo utilizaremos indistintamente los términos "silencio" y "acto silencioso" como equivalentes, sobre todo, por motivos estilísticos, pero serán objeto de nuestro estudio todas las ausencias de habla superiores a 1 segundo que tengan intención comunicativa.

${ }^{3}$ Para futuros estudios sobre el silencio, proponemos atender la noción de significados presumibles presentada por Levinson (2000) incorporando, eso sí, factores culturales que son determinantes sobre el uso de este elemento paralingüístico. El autor explica que, en el proceso inferencial, los hablantes se sirven de unos principios universales cognitivos (significados presumibles) que guían la construcción e interpretación de los enunciados y conducen a su implicatura. Tales principios funcionan por defecto y de manera constante, de forma que el hablante tiene en mente tanto lo que se dice como lo que
} 
En las últimas décadas y desde distintos enfoques lingüísticos -como la etnografía de la comunicación, la semiótica o el análisis de la conversación- se han presentado algunas taxonomías sobre el silencio que destacan su carácter como elemento altamente comunicativo.

Saville-Troike (1985: 16-17), al referirse al comportamiento comunicativo de los seres humanos, propone una clasificación etnográfica en la que distingue tres tipos de silencios: "aquellos determinados institucionalmente", "los promovidos por el grupo" y "el silencio individual". Entre los primeros se encontrarían, por ejemplo, los silencios rituales, los de los grupos religiosos, los propios del tabú, los indicativos de jerarquías sociales, etc.; entre los segundos se distingue entre el silencio situacional, el silencio normativo y el silencio simbólico; por último, entre los silencios determinados individualmente, se señalan los interactivos (entre los que se encuentra el sociocontextual, el lingüístico y el psicológico) y los no interactivos (constituidos por el silencio contemplativo o meditativo y el inactivo).

Un enfoque más funcional es el de Jaworski $(1993,1997)$, que interpreta los conceptos de silencio y habla como integrantes de un continuum y no como términos antagónicos y propone, a su vez, una escala del silencio desde los valores más negativos a los más positivos. Los valores más negativos estarían relacionados: con la expresión y/o muestra de varios estados emocionales y cognitivos; con la manera de señalar transiciones en la vida colectiva (ritos, ceremonia, etc.); o con los actos de resistencia, muestras de respeto, desafío al poder o autocensura. Por otro lado, los valores más positivos tendrían que ver: con los comportamientos silenciosos por motivos estéticos o artísticos; con lo que se deja sin decir, o a la habilidad de escuchar.

Gallardo $(1993,1996)$, desde el análisis de la conversación, diferencia y define el silencio, un silencio y una pausa. El silencio, que es la "ausencia de habla durante un tiempo amplio", no forma parte de la conversación. Según Gallardo, este tipo de silencio queda excluido de la interacción y se encuentra en distribución complementaria respecto a esta; un silencio sí pertenece, en cambio, a la conversación y es el que se da entre intervalos; por último, las pausas serían los silencios presentes dentro de un mismo turno de habla.

Poyatos (1994), desde sus trabajos sobre comunicación no verbal, también se refiere a las funciones positivas y negativas del silencio y lo hace desde un punto de vista interactivo. Como funciones positivas menciona el silencio natural del ambiente, el silencio

podría haberse dicho. Así, la interpretación preferida de los actos comunicativos dependerá, pues, de esos significados presumibles que son interpretaciones sistemáticas. 
de "rapport" ("siendo las palabras innecesarias para la comunicación, crecen en profundidad los sentimientos mutuos"), el silencio del amor compasivo ("que une en lugar de separar") y el silencio profesional (entre médico paciente, etc.). Como funciones negativas distingue entre el silencio para expresar actitudes negativas (como negación de comunicación) y el silencio manipulativo ("utilizado intencionalmente sabiendo que la ansiedad que causa está en proporción directa a su duración”) (Poyatos, 1994: 179-180).

En el análisis del discurso, Bilmes (1994) ha distinguido entre silencio absoluto u objetivo (absolute silence) y el silencio notable (notable silence), cuyo principal subtipo es el silencio conversacional. El primero de ellos hace referencia a la simple ausencia de sonido; en cambio, el segundo denota una ausencia relevante de sonido, "it is only when talk is relevant that we get conversational silence" (1994: 74). A su vez, este autor divide el silencio conversacional en dos subtipos: el explícito, el "no decir nada" ante un estímulo verbal, lo que indica una falta de interés, y el implícito, cuando se contesta con palabras pero solo "por decir algo": "some silences are obscured by words" (Bilmes, 1994: 83).

Kurzon $(1997,2007)$, desde un punto de vista semiótico, explica las relaciones "contrarias" entre el habla y el silencio, pues entiende que una persona no puede hablar y estar en silencio al mismo tiempo. En la interacción ideal, se alternan habla-silenciohabla: cuando una persona habla, la otra escucha (Kurzon, 1997: 11). Sin embargo, en esta explicación el mismo autor observa una paradoja cuando se plantea que la ausencia de comunicación (sin interacción) no implica silencio, porque este se entiende como actividad comunicativa. Posteriormente, planteará una clasificación de los silencios en las interacciones sociales. Así, distingue entre silencios conversacionales (equivalen a un acto de habla); silencios temáticos (mientras que en los silencios conversacionales el hablante no tiene nada que decir, en los temáticos ocurre que no tiene nada que decir respecto al tema que están tratando: política, religión, machismo...); silencios textuales (si en los silencios temáticos se guarda silencio sobre un tema específico, este tipo de silencio se produce en contextos en los que se lee un texto en silencio; sería, por tanto, el silencio propio de las bibliotecas); silencio situacional (mientras que el silencio textual se produce cuando los hablantes están leyendo en silencio, el situacional es el que se produce en algunos lugares que son propicios para ello como tribunales, escuelas, hospitales, funerarias, prisiones, campos de batalla, etc.) (Kurzon, 2007: 1666-1684).

Por su parte, Cestero (1999: 30-31), partiendo de un estudio global de la comunicación no verbal, propone una clasificación de las funciones comunicativas de los signos paralingüísticos y quinésicos entre los que se encuentran los silencios. Apunta a la plurifuncionalidad de los signos no verbales, los cuales pueden cumplir las siguientes funciones: añadir información al contenido o sentido de un enunciado verbal o matizarlo 
(especificando su contenido, confirmándolo, reforzándolo, debilitándolo, contradiciéndolo o camuflándolo); comunicar sustituyendo al lenguaje verbal; regular la interacción; subsanar deficiencias verbales; o intervenir en conversaciones simultáneas.

Nakane $(2005,2007$ y 2010) presenta un enfoque más cultural en el que el silencio se entiende como un fenómeno influido por múltiples factores sociales y culturales y aboga por la importancia de considerar la intencionalidad del silencio como uno de los aspectos más importantes. De esta manera, identifica el silencio como intencional (el que se utiliza voluntariamente como estrategia) y no intencional (provocado involuntariamente, debido a la ansiedad extrema, la vergüenza o el pánico).

Finalmente, y en el marco de una lingüística de corte más estructuralista, Ephratt (2008) revisa el modelo comunicativo clásico de Jakobson y asigna al silencio cada una de las funciones que se incluían en este modelo. Respecto a la función referencial, dice del silencio como signo lingüístico (signo cero) que trasmite información; de la función emotiva plantea que es una forma icónica afectiva de expresar emociones; en cuanto a la función conativa concluye que el silencio se utiliza tanto en los actos de habla directos como en los indirectos; en la función poética habla de la censura, las metáforas y las elipsis como algunas de sus representaciones; en la función fática, el silencio se utiliza para mantener un contacto permanente y de alianza; y en la función metafísica, el silencio es, entre otras cosas, una "marcador discursivo".

Todas estas clasificaciones nos han llevado a proponer una taxonomía pragmática sobre el silencio en la conversación en español (Camargo y Méndez, en prensa) a partir del análisis de un corpus de conversaciones espontáneas entre hombres y mujeres de 15 horas de duración que utilizaremos en este estudio. Distinguimos en un primer nivel entre silencios discursivos, silencios estructuradores y silencios epistemológicos y psicológicos. 


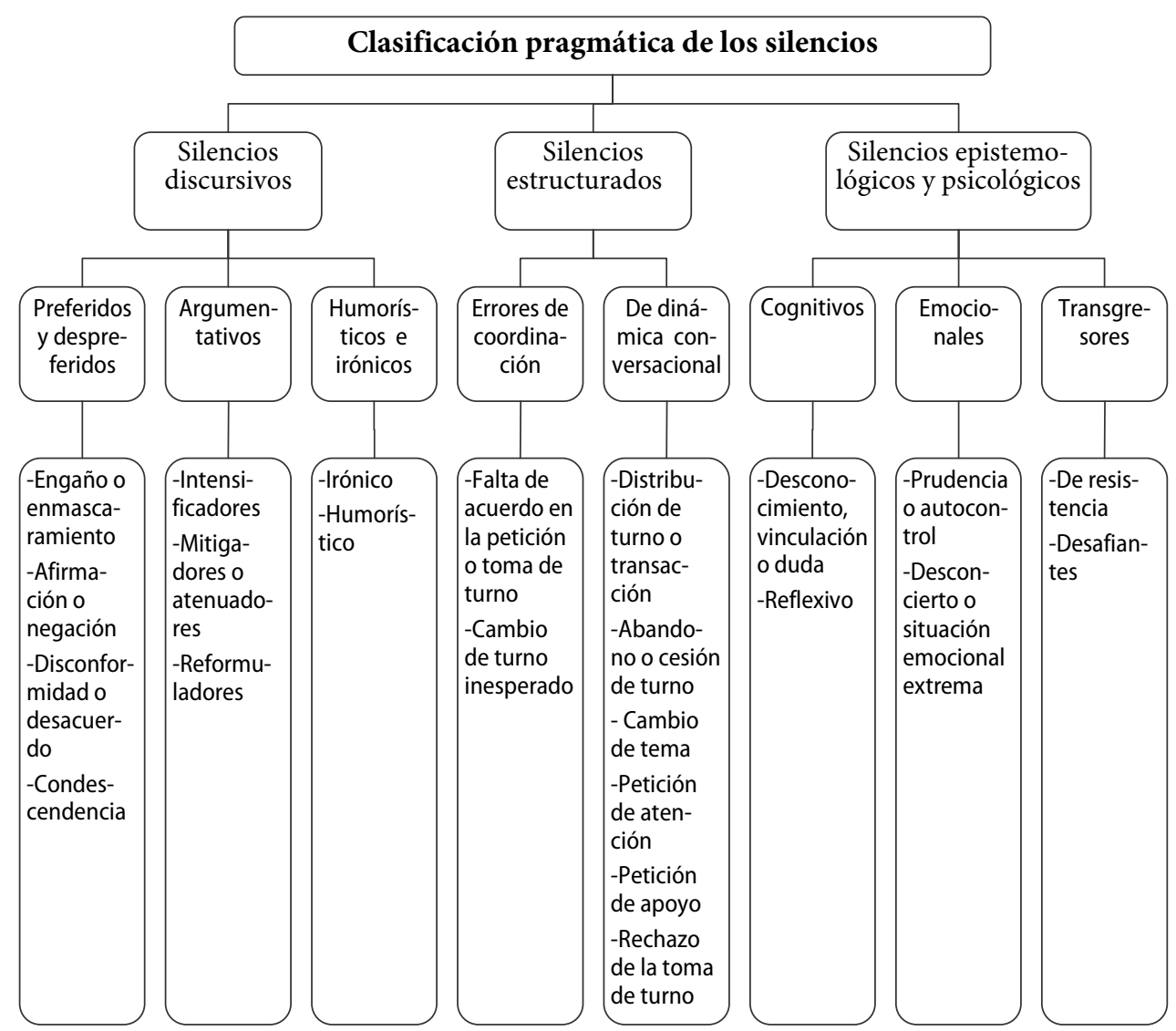

Figura 1. Taxonomía pragmática de los actos silenciosos (Camargo y Méndez, en prensa)

Los silencios discursivos tienen la finalidad de indicar una función comunicativa y facilitar tanto el procesamiento como la producción del discurso. Estos silencios orientan al receptor sobre la intención comunicativa del orador y cuentan con un significado determinado por el contexto y la situación comunicativa. Consideramos este tipo de silencios como mecanismos que nos asisten en el procesamiento inferencial, que es el que hace posible la interpretación completa de los enunciados. Además de orientar las inferencias, estos silencios, muchas veces, propician la comunicación haciendo que el discurso avance. En esta categoría encontraríamos los silencios preferidos y despreferidos (engaño o enmascaramiento, afirmación o negación, disconformidad o desacuerdo y condescendencia); los silencios argumentativos (intensificadores, mitigadores o atenuadores y reformuladores) y los silencios humorísticos e irónicos. 
(1) Ejemplo de silencio discursivo [EF.2.I4;I5]

I4 e I5 son amigos, tienen entre 20 y 25 años. Tema: I4 le comenta a I5 lo difícil que resulta aparcar en una calle en concreto, con lo que I5 no está de acuerdo.

I4: me parece súper complicado aparcar en esta calle y más a estas horas// es imposible del todo

I5: ///(2) depende/ por las tardes no es tan complicado

I4: chico/ pues en mi caso no hay manera// tengo más mala suerte

I5: bueno mujer///(1) tampoco es para tanto///(1) igual es que no buscas bien

En (1) el informante recurre al silencio para disentir con su interlocutor sobre lo que está expresando de manera más implícita. Ante la posible respuesta despreferida, I5 opta por callar y no mostrar tan explícitamente su desacuerdo con tal de que su interlocutor no entienda esta intervención como un ataque hacia él (que no se vea como el blanco de la objeción) y que esta situación no afecte a la relación entre los participantes. Por ello el silencio adquiere un valor de refutación, de desacuerdo; en suma, el hablante realiza un movimiento discursivo que contradice el enunciado anterior (o determinados aspectos del mismo) manifestando una posición contraria a lo expuesto.

Los silencios estructuradores forman parte de la estructura interna de la conversación española, ya que no siempre se produce una distribución regular de los turnos y a menudo se solapan, se superponen parcialmente o no se inician a tiempo. Siendo así, puede considerarse que el silencio resultante de esta distribución no siempre regular de los turnos forma parte de la interacción conversacional. Aquí situamos los silencios por errores de coordinación (falta de acuerdo en la petición o toma de turno y cambio de turno inesperado); y los silencios de dinámica conversacional (distribución de turno o transacción, abandono o cesión de turno, cambio de tema, petición de atención, petición de apoyo y rechazo de la toma de turno).

(2) Ejemplo de silencio estructurador [CE.3.H0;H4] (2088-2098)

H0 y H4 son amigos, tienen entre 20 y 25 años. Tema: H4 es músico y están hablando de su profesión.

\footnotetext{
${ }^{4}$ En el apartado 6 se presentan las convenciones de transcripción utilizadas. Entiéndase que en cada ejemplo serán únicamente objeto de análisis los silencios destacados en gris. La forma en la que presentaremos los silencios será la siguiente: tres barras y un número entre paréntesis que indica los segundos que dura dicho silencio: "///(2)" = silencio de 2 segundos de duración. El resto de silencios estarán representados de la misma forma pero permanecerán en el mismo color que el resto del texto. Por último, las pausas (por ser ausencias de habla inferiores a un segundo) se representarán con doble barra: //.
} 
H0: y lo mismo cuando cantas en un coro// que tienes otra voz a lo mejor por debajo y tú ya no sabes cuándo tienes que entrar (risas= TODOS) y es un lío y: ¡ah:! ¡terrible!

H4: ya pero eso es acostumbrarte///(1) es que eso:///(1) es normal que te pase// pero cuando llevas muchos años tocando no:// es más cuando llevas muchos años tocando/ si no escuchas la otra voz// ya es cuando tú dices// hey hey: que aquí

H0: que aquí pasa algo

H4: sí

H0: voy yo fuera///(1,5)

H4: incluso:///(1) cuando tú:// nosotros contamos compases ¿no?///(1) lo sabes ¿no? lo de: uno// dos// tres

Como apuntábamos anteriormente, en la conversación pueden producirse periodos de habla discontinua (Sacks et al., 1974) a causa de errores de coordinación entre los hablantes que dan lugar, entre otras cosas, a solapamientos y silencios. En el ejemplo (2) puede observarse cómo el silencio se produce por una conclusión abrupta o inesperada del turno de H0. A consecuencia de este ofrecimiento de turno inesperado, $\mathrm{H} 4$ se ve en la "obligación" de tomar la palabra e iniciar un nuevo turno de habla.

Por último, los silencios epistemológicos y psicológicos surgen en relación al estado psicológico o emocional de los hablantes en la interacción. Las personas tendemos a expresar nuestros sentimientos y emociones a través del discurso, pero también mediante la falta de él. De este modo, uno de los indicadores más representativos en la conversación española de las emociones, sentimientos, estados de ánimo, deseos, dudas o vacilaciones, voluntades y grado de interés es el silencio. Formarían parte de este tipo los silencios cognitivos (desconocimiento, vacilación o duda y los reflexivos); los silencios emocionales (prudencia o autocontrol y desconcierto o situación emocional extrema); y los silencios transgresores (aquellos que muestran resistencia ante las demandas del interlocutor).

(3) Ejemplo de silencio epistemológico y psicológico [CE.5.H0;H7] (1556-1561)

H0 (mujer) y H7 (hombre) son amigos, tienen entre 20 y 25 años. Tema: hablan del precio de la comida en el extranjero.

H7: no no/ no/ era otra cosa que era de: España// no sé por qué/ no/ tomates eran de España/ eran baratos

H0: ¿qué llamas barato?// ¿un euro y medio?

H7: no/ era más barato que aquí/ no me acuerdo/ no sé/ pero yo es que ahora no compro///(1) no los compro yo ahora// no no sé a qué precio están ahora// los de "ramallet" son carísimos/ pero allí no había///(4) 
H0: qué curioso

El tipo de silencio de (3) debilita en alguna medida el contenido de la enunciación, pues el hablante manifiesta inseguridad, ya que o bien desconoce lo que está diciendo y, por ello, duda o vacila en la explicación, o bien no recuerda en ese preciso instante lo que quiere comunicar.

La siguiente tabla recoge, a modo de síntesis, las taxonomías propuestas hasta la fecha en relación al silencio que han sido explicadas en este apartado.

\section{Taxonomías lingüísticas de los silencios}

\begin{tabular}{|c|c|c|c|}
\hline Saville-Troike (1985) & Jaworski $(1993,1997)$ & Gallardo $(1993,1996)$ & Poyatos (1994) \\
\hline $\begin{array}{l}\text { "El silencio es parte } \\
\text { integral del marco } \\
\text { cultural del habla" }\end{array}$ & $\begin{array}{l}\text { "El silencio y el } \\
\text { habla como un } \\
\text { continuum" (desde } \\
\text { formas más cercanas } \\
\text { al silencio a otras } \\
\text { más propias del } \\
\text { habla) }\end{array}$ & $\begin{array}{l}\text { “El silencio es la } \\
\text { ausencia de habla } \\
\text { durante un tiempo } \\
\text { amplio y no forma } \\
\text { parte de la conversa- } \\
\text { ción. Un silencio, en } \\
\text { cambio, sí pertenece } \\
\text { a la conversación y } \\
\text { se produce durante } \\
\text { un intercambio” }\end{array}$ & $\begin{array}{l}\text { "El silencio } \\
\text { sería la ausencia } \\
\text { de sonido } \\
\text { mientras que la } \\
\text { quietud hace } \\
\text { referencia a la } \\
\text { ausencia de } \\
\text { movimiento" }\end{array}$ \\
\hline $\begin{array}{l}\text {-Silencios institucionales } \\
\text {-Silencios grupales } \\
\text {-Silencios individuales }\end{array}$ & $\begin{array}{l}\text {-Expresión de sentimien- } \\
\text { tos y pensamientos } \\
\text {-Ritos, ceremonias } \\
\text {-Actos de resistencia } \\
\text {-Muestra de respeto } \\
\text {-Desafío al poder } \\
\text {-Autocensura } \\
\text {-Motivos estéticos o } \\
\text { artísticos } \\
\text {-Habilidades de escu- } \\
\text { char }\end{array}$ & $\begin{array}{l}\text {-El silencio } \\
\text {-Un silencio } \\
\text {-La pausa }\end{array}$ & $\begin{array}{l}\text {-Funciones positi- } \\
\text { vas } \\
\text {-Silencio natural } \\
\text {-Silencio de } \\
\text { "rapport" } \\
\text {-Silencio del amor } \\
\text {-Silencio profesio- } \\
\text { nal } \\
\text {-Funciones nega- } \\
\text { tivas } \\
\text {-Para expresar } \\
\text { actitudes negati- } \\
\text { vas } \\
\text {-Silencio manipu- } \\
\text { latorio }\end{array}$ \\
\hline
\end{tabular}



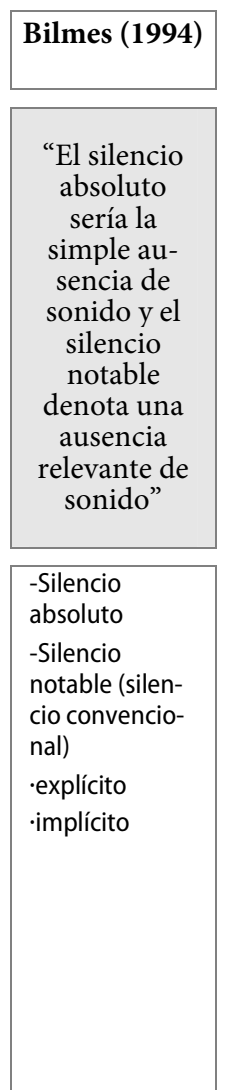

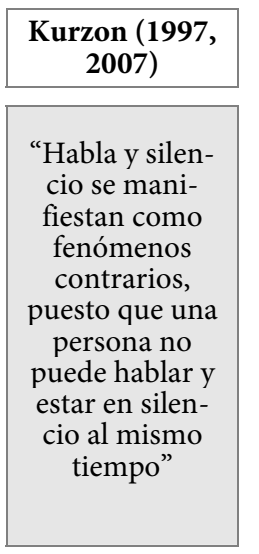

-Silencios conversacionales

-Silencios temáti$\cos$

-Silencios textuales

-Silencios situacionales

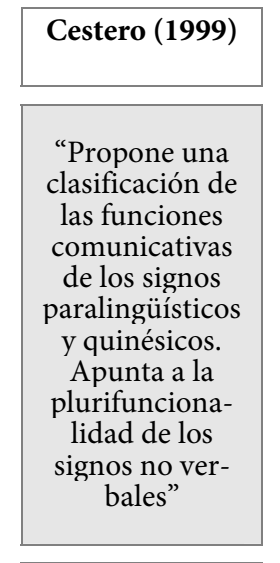

-Añadir información o matizarla

-Comunicar sustituyendo al lenguaje

-Regular la interacción verbal

-Subsanar deficiencias verbales

-Intervenir en conversacionesimultáneas

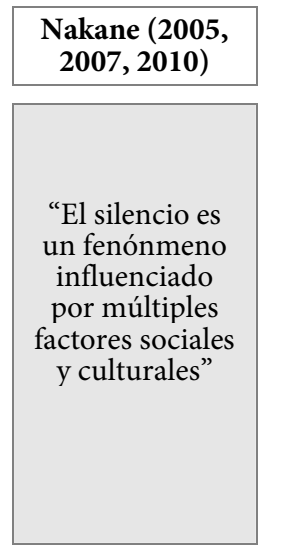

-Funciones positivas

-silencio natural -silencio de "rapport"

-silencio del amor -silencio profesional

-Funciones negativas

- para expresar

actitudes negati-

vas

-silencio manipulativo

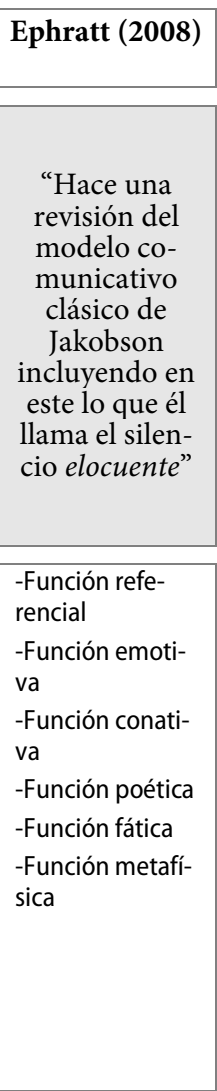

Figura 2. Cuadro-resumen de estudios sobre el silencio

\section{3. (Des)cortesía y silencio}

Basándose en el concepto de imagen propio de las sociedades orientales (en especial de la china), Goffman (1967: 5) definió el concepto de face como "the positive social value a person effectively claims for himself by the line others assume he has taken during a particular contact", o, lo que es igual, la imagen pública que los individuos construyen de sí mismos. Todos los estudios posteriores sobre la cortesía, entendida como un conjunto de estrategias conversacionales destinadas a evitar o mitigar los conflictos que surgen en las interacciones cotidianas, son en alguna medida deudores de esta definición goffmaniana. Como se sabe, sin embargo, la obra más citada y seguida —incluso para avanzar sobre ella, matizarla y mejorarla críticamente- es la que firmaron Brown y Levinson en 1987. Los autores de Politeness expusieron las estrategias desarrolladas por los sujetos en la interacción conversacional para cooperar en el mantenimiento de 
su imagen. Esta necesidad de mantener y salvaguardar la imagen viene de su vulnerabilidad y de la gran cantidad de actos potencialmente amenazadores para la misma que Brown y Levinson denominaron FTAs (Face Threatening Acts). Según explican, la imagen tiene dos vertientes: la positiva, o la necesidad de ser aceptado, de ser solidario y de agradar a los demás, y la negativa, o la necesidad de conservar la independencia, tener libertad de acción y de que los demás no se impongan (Brown y Levinson, 1987: 62 y ss.).

A partir de este trabajo, es mucho lo que se ha desarrollado esta vertiente sociocultural de la pragmática, ampliando el ámbito de estudio de la cortesía hasta la (des)cortesía y reconociendo también otros niveles posibles como la acortesía y la supercortesía (Kerbrat-Orecchioni, 2004: 49). Al igual que ocurre con la cortesía, el nivel de (des)cortesía debe evaluarse siempre en contexto y en función de la cultura de la que se trate. Esto es así hasta tal punto que puede pensarse que en muchas de nuestras interacciones sociales el fin último no es alcanzar o mantener una armonía y evitar o mitigar conflictos, tal y como proponían Brown y Levinson (1987), sino crear un conflicto en el cual encajarían algunos actos descorteses cotidianos. Para dichos casos, tal y como propone Bernal (2007), la visión de la cortesía resulta quizás demasiado positiva u optimista al considerarla como algo deseable y a lo que se debe aspirar, sin tener en cuenta que, para ciertos hablantes, esto puede no ser tan importante.

Por otro lado, cabe destacar que autores como Mills (2003) han catalogado la descortesía como un elemento "especialmente difícil de clasificar" (Mills, 2003: 134), ya que, en ocasiones, ni para los mismos participantes está claro si alguien ha sido (des)cortés o no. A ello se suma que muchas veces su efecto es acumulativo: leves amenazas pueden llegar a constituir descortesía tras una acumulación de incidentes: "It is only when impolite acts are 'addep up', or viewed in a cumulative way, and when it is assumed that the speaker intended to be impolite that they constitute a threat to the face of the hearer and to the community of practice" (Mills, 2003: 136).

En cualquier caso, como señala Albelda (2004), es fundamental tener en cuenta tanto el tipo de relación existente entre los interlocutores como las variables sociológicas de los participantes, la temática que se está tratando y la finalidad discursiva. En general, los actos amenazadores para la imagen en la cultura española son aquellos que dañan el prestigio público de la persona a la que van dirigidos, que le hacen quedar mal, que le critican o insultan, en definitiva, que le humillan o le empujan a desempeñar alguna tarea sin respetar su libertad de acción. Lingüísticamente, se pueden manifestar de muchas formas como, por ejemplo, a través de imperativos, insultos, reprimendas, por medio de énfasis prosódico, con apelaciones directas al tú, a olvidos o equivocaciones, etc., que afectan o implican la esfera personal del tú (Albelda, 2004: 334). 
Al hablar de los aspectos metalingüísticos de la cortesía, Leech (1997: 222) plantea que ciertas conductas conversacionales como hablar a destiempo, interrumpiendo, o permanecer inadecuadamente en silencio tienen implicaciones descorteses. Por su parte, Haverkate (1994) afirma que seguir la conversación y evitar el silencio en la lengua/cultura española es un tipo de cortesía metalingüística. De estas palabras se desprende la idea de que los hablantes son conscientes de que el silencio es "molesto" en nuestra sociedad y que no se debe "abusar" de su uso.

Sifianou (1997) subraya que las sociedades con una orientación a la cortesía negativa valoran más el silencio que las sociedades en las que predomina la cortesía positiva. Esta hipótesis se deduce de las propias definiciones de cortesía positiva y negativa. Mientras que la cortesía negativa se centra en el deseo de que el hablante sea libre, la cortesía positiva se basa en la pertenencia al grupo de personas que comparten puntos de vista. Esta afirmación -advierte Sifianou- no debe interpretarse en el sentido de que el silencio no tenga cabida en una sociedad con una orientación a la cortesía positiva o que el hecho de hablar se reduzca al mínimo en sociedades consideradas de cortesía negativa; simplemente significa que los silencios variarán en su función interpersonal dependiendo de la lengua/cultura en cuestión.

Más recientemente, Kaul de Marlangeon (2008) ha presentado una tipología del comportamiento comunicativo descortés en la cultura hispanohablante aludiendo a un acto silencioso en particular. La autora agrupa los actos descorteses según la intención del hablante y el grado de lesión que se inflige al receptor. Entre las categorías descorteses que propone se encuentra lo que denomina silencio abrumador, del que dice que "no es una mera ausencia de respuesta, una pregunta o una aserción; el oyente esgrime deliberadamente su silencio para indicar desacuerdo con el hablante, a pesar de que el contexto de situación y el compromiso entre los interlocutores le impelerían a una respuesta concordante y a un encadenamiento preferido de aquiescencia" (Kaul de Marlangeon, 2008: 261).

Dicho todo lo anterior, a la hora de establecer una relación entre (des)cortesía y silencio, se deben tener en cuenta factores que determinarán en qué medida el silencio es (des)cortés. Para nuestro análisis, nos hemos basado en las nociones de duración y coste-beneficio.

\subsection{Duración de los actos silenciosos y (des)cortesía}

$\mathrm{Al}$ ser la española una cultura de cortesía positiva en la que predomina la palabra, defendemos que los actos silenciosos representarán mayor riesgo para la imagen social del hablante (face) cuanto más largos sean y que, por tanto, pueden ser interpretados 
como más descorteses. Se entiende que la face es la imagen pública que cada individuo tiene y reclama para sí. Según Brown y Levinson (1987), esta imagen presenta dos vertientes: por un lado, el deseo de no sufrir imposiciones; y por otro, el deseo de ser apreciado. Así las cosas, no dañar la imagen ajena y salvaguardar la propia son la mejor manera de entablar y mantener buenas relaciones sociales. Siguiendo la idea de Campos y Romera (2012), pensamos que esta imagen de los hablantes no es monolítica, es decir, no es estática, sino que se negocia en cada encuentro dependiendo de la situación en la que nos hallemos y de la relación social, siempre única, existente entre los interlocutores.

En lo que a los datos del estudio se refiere, hay que destacar, en primer lugar, que el análisis se basa en un corpus de conversaciones espontáneas, recogidas mediante la técnica de grabación secreta ${ }^{5}$, de 15 horas de duración. La muestra cuenta con las interacciones de 10 hablantes españoles jóvenes ( 5 mujeres y 5 hombres menores de 25 años) de distinta procedencia ( 8 de ellos han nacido y vivido en Mallorca, aunque sus familias son peninsulares, y los otros 2 son valencianos). Las conversaciones se produjeron de manera totalmente natural y espontánea, y tuvieron lugar en contextos altamente familiares y en localizaciones muy frecuentadas por los informantes. Para la medición y el tratamiento de los silencios se utilizaron los programas PRAAT y SPSS respectivamente, y las grabaciones, además, fueron transcritas mediante las convenciones de PRESEEA $^{6}$. En lo que se refiere a la selección de los hablantes del corpus, conviene precisar que el muestreo se realizó de forma intencionada (descartando así el factor azar) y que estos informantes constituyen un grupo social compacto ya que son miembros de una red social muy concreta: jóvenes universitarios menores de 25 años y con una relación de familiaridad muy alta entre ellos. Decidimos hacerlo así con el fin de conseguir muestras lo más informales y espontáneas posibles. Los hablantes, que desconocían que estaban siendo grabados, se mostraron totalmente naturales y espontáneos en sus intervenciones ${ }^{7}$.

\footnotetext{
${ }^{5}$ Todos los informantes dieron su consentimiento al finalizar la grabación.

${ }^{6}$ PRESEEA (2008): “Marcas y etiquetas mínimas obligatorias”, Versión 1.2. 31-01-2008.

http://www.linguas.net/preseea.

${ }^{7}$ Un problema recurrente en este tipo de estudios es delimitar los elementos que forman parte en mayor medida del idiolecto del hablante y de su variedad social o dialectal. Somos conscientes de que incluso un individuo perteneciente a un grupo homogéneo y compacto puede presentar rasgos propios o exclusivos que no comparte con otros miembros del grupo. Es decir, puede haber hablantes más callados y otros más locuaces. Lo que ha primado en este estudio al realizar la selección de los informantes ha sido el hecho de lograr conversaciones espontáneas y en las que a los participantes les unieran lazos estrechos, ya que es en estos contextos de espontaneidad y cercanía en los que creemos que el
} 
En el corpus de datos manejado se observan un total de 1825 actos silenciosos de los cuales solo un tercio son silencios (662 casos). A partir del análisis de estos silencios y de la relación que guardan con las pausas hemos podido catalogar algunos silencios como más corteses y otros como más descorteses, y lo hemos hecho en base a dos criterios: las funciones que suponen un mayor coste para el oyente y la duración de los silencios.

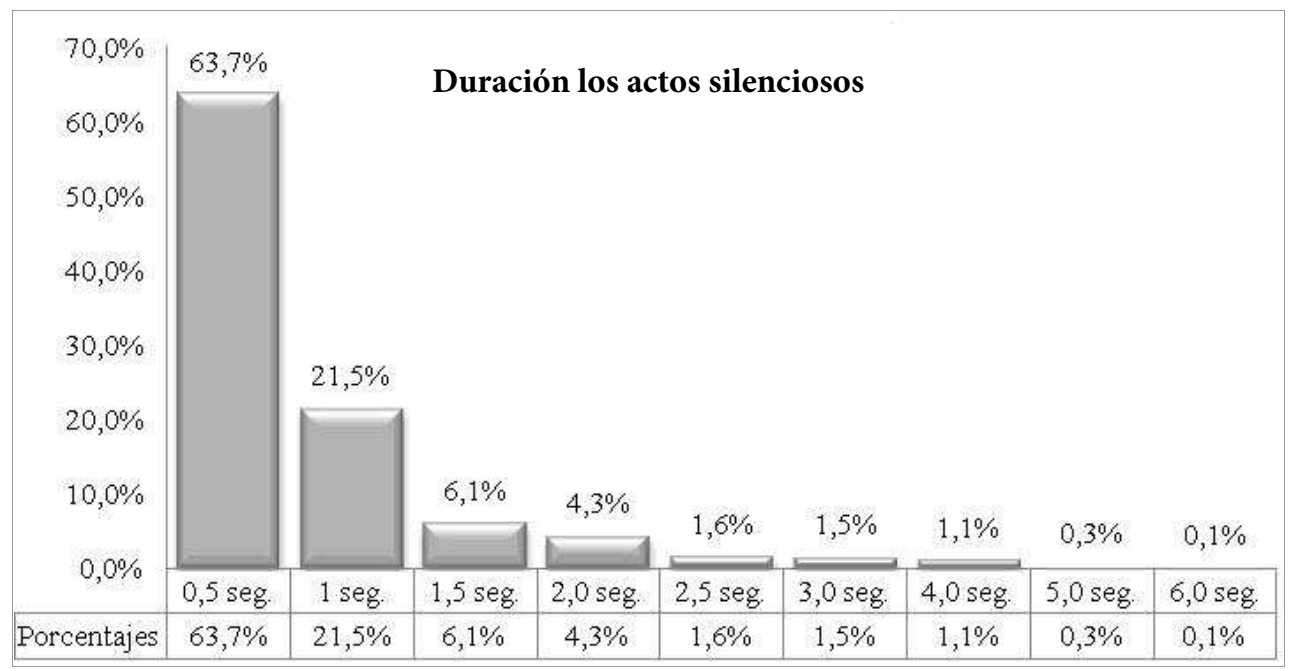

Figura 3. Porcentajes de duración de los 1825 actos silenciosos recogidos en la muestra

El primer dato relevante de la gráfica es que casi dos tercios de los actos silenciosos recogidos en el corpus son pausas, es decir, su duración es inferior a un segundo. Esto, unido a la baja frecuencia con la que aparecen silencios superiores a dos segundos, permite reforzar la idea de partida de que la cultura española es poco dada al silencio. Presentamos este dato para ilustrar lo anterior, puesto que ya advertimos que las pausas no forman parte de nuestro estudio. Las cifras que se indican a continuación representan

silencio "se permite" más o no se ve tanto como una amenaza. Es necesario insistir, también, en que la relación social entre los participantes no está fijada de antemano en la conversación, sino que se establece y se negocia en cada encuentro comunicativo, dependiendo de los factores lingüísticos y extralingüísticos que intervengan en cada interacción. Por otra parte, este análisis habrá que contrastarlo con un corpus de conversación más formal, con el fin de determinar si en contextos formales -en los que las relaciones sociales son diferentes a las analizadas aquí- los silencios se utilizan con las mismas funciones y en la misma medida. 
los porcentajes de los actos silenciosos aparecidos en la muestra en relación a la función que desempeñan y a su duración.

\begin{tabular}{|c|c|c|c|c|c|c|c|c|c|c|}
\hline & $\begin{array}{c}\text { Auto- } \\
\text { control }\end{array}$ & $\begin{array}{c}\text { Descono- } \\
\text { cimiento }\end{array}$ & $\begin{array}{c}\text { Refle- } \\
\text { xivo }\end{array}$ & $\begin{array}{c}\text { Petición } \\
\text { Apoyo o } \\
\text { Atención }\end{array}$ & $\begin{array}{c}\text { Intensifi- } \\
\text { cador }\end{array}$ & $\begin{array}{c}\text { Mitiga- } \\
\text { dor }\end{array}$ & Humor & Ironía & $\begin{array}{c}\text { Refor- } \\
\text { mulador }\end{array}$ & $\begin{array}{c}\text { Cambio } \\
\text { de tema }\end{array}$ \\
\hline$<1$ & $62,2 \%$ & $52,1 \%$ & $57,6 \%$ & $45,8 \%$ & $60,9 \%$ & $76,2 \%$ & $73,5 \%$ & $42,9 \%$ & $86,7 \%$ & $15,4 \%$ \\
\hline$\geq 1$ & $38,8 \%$ & $47,9 \%$ & $42,4 \%$ & $54,2 \%$ & $39,1 \%$ & $23,8 \%$ & $25,5 \%$ & $57,1 \%$ & $13,3 \%$ & $84,6 \%$ \\
\hline
\end{tabular}

Figura 4. Tabla de porcentajes de los actos silenciosos según su duración ${ }^{8}$

Como se aprecia en la tabla, las funciones que tienen un mayor índice de producción como ausencias de habla más largas son los silencios por cambio de tema, los silencios irónicos, y, a poca distancia, los silencios por petición de atención y apoyo (véanse, como muestra de ello, los ejemplos 4, 5, 6 y 7 que a continuación se presentan). Ya en otro nivel, por debajo del 50\%, observamos aquellos a los que se recurre por desconocimiento, vacilación o duda, los reflexivos, los intensificadores y los de autocontrol. Por último, con niveles inferiores, hallaríamos los silencios humorísticos y al final de la tabla los reformuladores y mitigadores. Estas funciones estarían más habitualmente representadas por pausas.

(4) Ejemplo de silencio por cambio de tema [CE.4.H0;H6] (949-962)

H0 y H6 son amigas, tienen entre 20 y 25 años. Tema: hablan de sus hábitos y costumbres.

H0: ¡ay! no me apetece comer comida basura otra vez// ando siempre mala del estómago// me he acostumbrado este año a malcomer// como iba corriendo del

\footnotetext{
${ }^{8}$ Algunos de los silencios que proponemos en la taxonomía no han quedado representados en la muestra posiblemente debido a que son más propios de otro tipo de contextos más formales, públicos o institucionales. Pensamos que este es el caso de los silencios preferidos y despreferidos ya que en conversaciones tan informales como las analizadas y entre hablantes con un grado de familiaridad tan alto se han utilizado estrategias más directas y explícitas para mostrar disconformidad o desacuerdo optando así por no enmascarar los actos disentivos. En el caso de los silencios por errores de coordinación, tampoco han quedado representados al existir una tendencia en nuestro corpus espontáneo a disputar los turnos de palabra a través de numerosas interrupciones y solapamientos que no dejan lugar a este tipo de ausencias de habla. Por último, algunos tipos de silencios afectivos tampoco aparecen en los datos recogidos, ya que entre este grupo de amigos tan cercanos y tan jóvenes la expresión de sentimientos se realiza mayormente a través de la verbalidad. Por todo ello, para futuros estudios sobre el silencio, vemos muy necesario el análisis de los actos silenciosos en otros contextos diferentes a los estudiados aquí para poder determinar si existen diferencias con las funciones aquí recogidas y también con las funciones que se proponen en la taxonomia presentada en el apartado 3 del presente artículo, que, como ya se ha comentado, provienen de un trabajo anterior (Camargo y Méndez, en prensa) y que nos ha servido de base de partida en este estudio.
} 
curro a clase y comía por el camino si es que comía///(1) y y estoy chunga chunga del estómago desde hace tiempo// no me apetece// comer aquí///(1) así que me parece que me pillaré un bocata de los de: arriba/ un sándwich

H6: bueno/ los de arriba están buenos/ a mí me gustan///(3) madre mía que yo: me tengo que poner a estudiar

El silencio de (4) cumple una función primordial en la conversación: propiciar el cambio de tema haciendo que esta avance. Esta función es una de las que presenta duraciones más altas en la muestra analizada. En este caso, H6 lo utiliza para conectar distintos temas de manera armoniosa sin que ello provoque una transición abrupta organizando las estructuras del discurso y conectándolas entre sí.

(5) Ejemplo de silencio irónico [CE.4.H0;H6] (949-962)

$\mathrm{H} 0, \mathrm{H} 1, \mathrm{H} 2$ y $\mathrm{H} 3$ son amigas, tienen entre 20 y 25 años. Tema: hablan de un simulacro de robo y bomba que ha presenciado en su lugar de trabajo.

$\mathrm{H} 2$ : "que he puesto una bomba, que no me toques las narices"// ha sido lo mejor porque estaba P./ yo con L. me estaba partiendo

H1: eh pero ¡qué guay tío!

H2: "que he sido trabajadora de aquí y me habéis puteado y ahora os he puesto una bomba"

H0: y ella "observaciones, dos puntos, exempleada" (risas= H0)/// (2)

H1: real como la vida misma///(1) yo lo voy a hacer

H2: y yo

Como juegos del lenguaje que son, las ironías necesitan y crean complicidad, pues "generalmente, los hablantes saben cuándo cuentan con unos mínimos acuerdos entre los participantes en la interacción para ser comprendidos [...]. El juego irónico y humorístico exige y genera, por tanto, complicidad, de forma que muchas transgresiones se construyen sobre la comunión de experiencias, expectativas y bagaje cultural que existe entre los interlocutores" (Camargo, 2009: 100-102). En el caso de (5), es la expresión "real como la vida misma" seguida de un elocuente silencio la que activa la complicidad entre los participantes y obliga a poner en marcha procesos inferenciales para la correcta recuperación de la implicatura irónica: "esto no ocurre nunca en la vida real".

(6) Ejemplo de silencio por petición de apoyo [CE.2.H0;H4] (888-903)

H0 (mujer) y H4 (hombre) son amigos, tienen 25 años. Tema: hablan de la falta de comunicación que se producen en relaciones de pareja.

H0: entonces/ yo como soy más cortés/ voy a intentar// emitir utilizar menos el silencio/ recurrir menos al silencio que tú 
H4: pero yo no lo intento llenar// claro/ claro/ pero yo no lleno el hueco porque para mí no me crea un problema// a las mujeres os crea un problema// más///(1) ¿vale?/ sobre todo en relación de pareja///(1) ¿vale?///(1) el novio callado os da más problema a una chica que a un// tío

H0: efectivamente

H4: vale pero

H0: $\quad$ y tenemos la sensación de que hay falta de comunicación

H4: exacto

H0: pero es porque hay falta de comunicación H4/ no es una sensación/ si tú no hablas y hablo yo sola como con una pared/ tú qué quieres que haga/ yo me molesto

H4: pero a ver hay cosas que ya se dicen solas///(1,5) ¿sabes?

El silencio en (6) se utiliza como un recurso apelativo para reclamar al oyente que coopere en la construcción de la interacción mostrando seguimiento del enunciado en marcha (Cestero, 2000: 114). Este tipo de silencios también suelen reforzar el valor ilocutivo del acto en el que aparecen y se utilizan como formas de hacer progresar la conversación.

(7) Ejemplo de silencio por petición de atención [CE.4.H0;H6] (740-748)

H0 y H6 son amigas, tienen entre 20 y 25 años. Tema: hablan del trabajo.

H6: y a mí si me lo hubieran dicho/ "mira que: se lo vamos a ofrecer a ella por este tema" pues yo "pues vale" ¿sabes?// yo hubiera dicho que sí/ hizo bien ¿sabes?// pero me da rabia que siendo ella la que vino a mí a decírmelo///(1) ¿sabes?// ¿por qué no me dijo a mí?///(1) porque yo no le dije nada a ella a mí me la rempampinflaba///(1) pero da rabia///(1) que va: con doble: cara/ ahora ya lo veo H0: pero si esto ha sido siempre

En el ejemplo (7) se aprecia cómo H6 intenta asegurarse de que su interlocutora sigue su discurso. En este caso, el silencio adquiere un valor fático y de mantenimiento de contacto, dado que el hablante reafirma lo dicho, llama la atención sobre el mensaje y pide la atención del oyente, si bien no espera su respuesta. Se trata, por tanto, de un uso estratégico del silencio.

\subsection{Impacto de los actos silenciosos en la imagen del interlocutor}

La cortesía, como principio regulador de la distancia social, puede definirse en términos de "coste" y "beneficio". Esta depende del coste o del beneficio que suponga el cumplimiento de la acción para el destinatario o el emisor. Así, la acción es intrínsecamente más "descortés” cuanto mayor es el coste para el destinatario y menor su benefi- 
cio; y, viceversa, es más "cortés" cuanto mayor sea el coste para el emisor y mayor el beneficio para el destinatario (Escandell, 2006: 364). Siguiendo esta idea de la que también parten Lakoff (1973), Leech (1983) y Brown y Levinson (1987), pensamos que aquellos silencios que supongan un mayor coste para los hablantes serán más descorteses que aquellos que, por el contrario, no tengan un riesgo tan alto para su imagen.

En función del impacto que pueden tener los actos comunicativos sobre las relaciones sociales, Escandell (1996), inspirándose en Leech (1983), propone una clasificación en la que recurre a los parámetros de coste-beneficio para asignar grados de (des)cortesía. De esta forma, distingue entre: (1) acciones que apoyan (o mejoran) la relación social; (2) acciones indiferentes; (3) acciones que entran en conflicto con la relación social; y (4) acciones dirigidas frontalmente contra la relación entre los interlocutores. Esta clasificación es la que hemos utilizado en el análisis para determinar los niveles de (des)cortesía de los silencios y lo hemos hecho atendiendo al riesgo que puede tener sobre la imagen ( face) cada una de las funciones de los silencios planteadas.

- Acciones que apoyan (o mejoran) la relación social: beneficio para el destinatario y coste para el emisor. Aquí se incluyen los silencios mitigadores o atenuadores, humorísticos, por autocontrol, los preferidos o despreferidos y los silencios por errores de coordinación. Esta agrupación nace al considerar que entre los jóvenes con una relación de amistad muy estrecha estos silencios tienen un menor riesgo para la imagen de los hablantes. Es decir, que el peligro para la relación social, independientemente de que finalmente esa amenaza desemboque o no en un acto descortés (véase el apartado de anticortesía), es muy bajo.

La función mitigadora o atenuadora de los silencios es utilizada por los hablantes de la muestra con el fin de mantener un equilibrio en la interacción y para proteger su propia imagen social y la de su interlocutor. Algo parecido ocurre con los silencios humorísticos que entre jóvenes están especialmente orientados al refuerzo de la solidaridad y a estrechar los lazos grupales. Por otra parte, las ausencias de habla por autocontrol también comportan un bajo coste para el receptor, ya que los hablantes (quizá teniendo en cuenta el dicho popular "más vale callar que errar") tienden a pensar antes de hacer explícito su discurso. Aunque ciertamente hay que destacar que este último tipo de silencios no es muy frecuente en el habla informal y espontánea de los hablantes

\footnotetext{
${ }^{9}$ Es importante aclarar que no necesariamente en todos los casos en los que exista riesgo para la face se verá esta afectada, ya que es imposible determinar con total certeza si nuestro acto silencioso va a causar un efecto (des)cortés sobre el oyente, se quedará en una sencilla amenaza, o no tendrá, incluso, ninguno de los dos efectos. Sobre esta cuestión se volverá más adelante al hablar de anticortesía.
} 
jóvenes de este corpus. Este es el caso también de los silencios preferidos y despreferidos que no han quedado representados en la muestra, pero a los que asignamos un valor de bajo coste para el receptor, pues se presentan como estrategias más indirectas o implícitas para ocultar o enmascarar los actos comunicativos. La inclusión de los errores de coordinación en este grupo se justifica por ser una confusión o falta de acuerdo involuntaria en la distribución de los turnos y no haber una intencionalidad expresa por parte de los interlocutores en la falta de coordinación.

- Acciones indiferentes: equilibrio entre coste y beneficio para los interlocutores. Formarían parte de este grupo los silencios reformuladores, los reflexivos, los intensificadores y aquellos a los que se recurre por desconocimiento. En este caso parece no haber un riesgo excesivamente alto en relación a si pueden causar daño o no sobre alguno de los hablantes, pero sin duda los beneficios sobre el interlocutor no son tan patentes, de ahí que los incluyamos en un estadio intermedio.

Los silencios reformuladores se erigen como estrategias para construir la argumentación y son utilizados principalmente para estar seguros de que el oyente comprende totalmente lo expresado cuando se comunica algo, por lo que no se vislumbra un claro desequilibrio entre el coste y el beneficio que aportan al receptor. En el caso de los reflexivos ocurre algo similar y es que los hablantes tienden a callar y reflexionar más su mensaje para que este sea claro y se entienda. Este silencio tampoco es muy frecuente entre los jóvenes del corpus analizado. Los silencios intensificadores son utilizados como estrategias enfatizadoras y cooperativas que se vinculan a la idea de fuerza argumentativa y que pretenden garantizar la buena marcha de la conversación y la atención del interlocutor. En último lugar, los silencios por desconocimiento, vacilación o duda tienen una función retardadora, pues el hablante gana tiempo para pensar y formular su intervención de forma exitosa, por lo que tampoco parece que supongan un coste demasiado grande para el receptor.

- Acciones que entran en conflicto con la relación social: implican algún coste para el destinatario. En estos últimos clasificaríamos los silencios por petición de atención, los que piden apoyo, los irónicos y los que propician el cambio de tema. Entiéndase que a estos silencios conllevan un riesgo mayor que el resto por poder causar con mayor facilidad (aunque no necesariamente tenga que ser así) un daño para la relación social de los interlocutores, en el sentido de que las acciones que promueven o demandan pueden ser malinterpretadas más fácilmente por los hablantes causando así actos considerados descorteses.

La función petición de atención se presenta en el corpus como una llamada de atención sobre el mensaje, se recurre a una función fática con la intención de reafirmar lo dicho y de llamar la atención del oyente, si bien no se espera respuesta. Por su parte, los 
silencios por petición de apoyo son sin duda un recurso apelativo o de petición de información adicional. Esta estrategia comunicativa es muy frecuente entre los jóvenes de nuestro corpus cuando reclaman la colaboración de su interlocutor o le piden más información marcando enfáticamente estas peticiones mediante el uso del silencio. Al pedir a los hablantes que hagan un mayor esfuerzo cognitivo y/o comunicativo y verse la libertad individual de estos potencialmente coartada, apreciamos en estos silencios un mayor coste para el receptor, por lo que han sido incluidos en un estadio más cercano a la descortesía. En cuanto a los silencios irónicos - como se ha dicho- en las muestras aparecen como un mecanismo de complicidad y afiliación entre los interlocutores y en su mayoría se enmarcan en las ironías de efecto positivo (Alvarado, 2005; Padilla y Alvarado, 2010), ya que no llevan implícita la burla o mofa sobre los interlocutores, pero aun así implican un riesgo mayor sobre la face que otros silencios al poder ser malinterpretados más fácilmente ${ }^{10}$. Los silencios por cambio de tema también están enmarcados en este nivel por el mayor coste que suponen para el receptor en los casos en los que no se utilizan de manera exitosa. El hablante puede pensar que es el momento ideal para introducir un nuevo tema y cumplir así con la tarea de mantener "viva" la conversación, pero si "comete un error" dando por concluido un tema e introduciendo otro nuevo cuando su interlocutor no lo considera oportuno, se puede producir un conflicto y verse su imagen gravemente dañada ya que puede parecer que se muestra poco interesado.

-Acciones dirigidas frontalmente contra la relación entre los interlocutores, es decir, acciones que pretenden acrecentar la distancia o destruir las relaciones existentes. En este tipo se incluyen los silencios por resistencia y los desafiantes, que son los que consideraremos más descorteses.

El silencio como forma de resistencia es una estrategia discursiva de subversión pasiva o indirecta (Martín Rojo, 2011). Este mecanismo entraña un mayor riesgo para la imagen del interlocutor y se utiliza sobre todo en contextos en los que existe una relación asimétrica entre los participantes como una manifestación de lucha por el poder. Estas formas de resistencia tienen un efecto libertador frente a las imposiciones del interlocutor, de ahí que el mayor coste sea para el receptor. En cuanto a los silencios desafiantes, son un intento deliberado de no cooperar con el interlocutor en relaciones

\footnotetext{
${ }^{10}$ En otros contextos estos mismos silencios pueden ser utilizados por los hablantes con efectos más negativos (como burla o crítica hacia algo o hacia alguien) y en estos casos el riesgo para la imagen del receptor será aún mayor.
} 
de poder-sumisión (Kurzon, 1995). El orador tiene siempre la opción del discurso y la del silencio y opta por este último para enfrentarse a su interlocutor. ${ }^{11}$

La tabla que sigue recoge las funciones pragmáticas del silencio en relación al costebeneficio de los actos comunicativos.

\begin{tabular}{|c|c|c|c|}
\hline $\begin{array}{l}\text { Actos silenciosos } \\
\text { que apoyan (o } \\
\text { mejoran) la rela- } \\
\quad \text { ción social } \\
\text { +beneficio para el } \\
\text { receptor } \\
\text {-coste para el receptor }\end{array}$ & $\begin{array}{l}\text { Actos silenciosos } \\
\text { indiferentes }\end{array}$ & $\begin{array}{l}\text { Actos silenciosos } \\
\text { que entran en con- } \\
\text { flicto con la rela- } \\
\quad \text { ción social } \\
\text { + coste para el recep- } \\
\text { tor }\end{array}$ & $\begin{array}{l}\begin{array}{l}\text { Actos silenciosos } \\
\text { dirigidos frontal- } \\
\text { mente contra la } \\
\text { relación }\end{array} \\
\text { Acrecientan la distan- } \\
\text { cia o destruyen rela- } \\
\text { ciones existentes }\end{array}$ \\
\hline $\begin{array}{l}\text { - Mitigadores } \\
\text { - Humorísticos } \\
\text { - Autocontrol } \\
\text { - Preferidos o despre- } \\
\text { feridos } \\
\text { - Errores de coordina- } \\
\text { ción }\end{array}$ & $\begin{array}{l}\text { - Reformuladores } \\
\text { - Reflexivos } \\
\text { - Intensificadores } \\
\text { - Desconocimiento }\end{array}$ & $\begin{array}{l}\text { - Petición de Atención } \\
\text { - Petición de Apoyo } \\
\text { - Irónicos } \\
\text { - Cambio de tema }\end{array}$ & $\begin{array}{l}\text { - Por resistencia } \\
\text { - Desafiantes }\end{array}$ \\
\hline
\end{tabular}

Figura 5. Tabla de funciones de los actos silenciosos en relación al parámetro coste-beneficio (a partir de Leech (1983) y Escandell (1996))

Tras este análisis y atendiendo a la duración y al coste-beneficio de las funciones de los actos silenciosos, proponemos la siguiente gradación en la que, como se puede observar, los actos silenciosos que suponen un mayor coste para el receptor son a la vez los más largos en duración y, por tanto, los más descorteses; de la misma forma, los más breves son a su vez los que le aportan un mayor beneficio o entrañan menor riesgo para la imagen, por lo que consideramos que serán los menos descorteses ${ }^{12}$.

\footnotetext{
${ }^{11}$ Estas funciones de los silencios tampoco han quedado reflejadas en los datos analizados, ya que este tipo de actos comunicativos no son frecuentes entre los hablantes de la muestra, quienes mantienen una relación social muy próxima.

${ }^{12}$ El análisis que acabamos de presentar ha sido contrastado con los resultados obtenidos en otro estudio efectuado a ocho informantes (4 hombres y 4 mujeres) del grupo Val.Es.Co (Briz, 1995). Este análisis se ha realizado con la intención de reducir el factor azar y de verificar que los resultados obtenidos no son fruto de la casualidad o se reducen al estilo comunicativo propio de un grupo concreto. Para ello revisamos un total de 157 fragmentos en las que aparecían silencios (dos transcripciones íntegras). Cabe destacar que los resultados obtenidos en este análisis son muy similares a los presentados en este trabajo. En primer lugar, observamos que el $70,1 \%$ de los silencios que aparecen en
} 


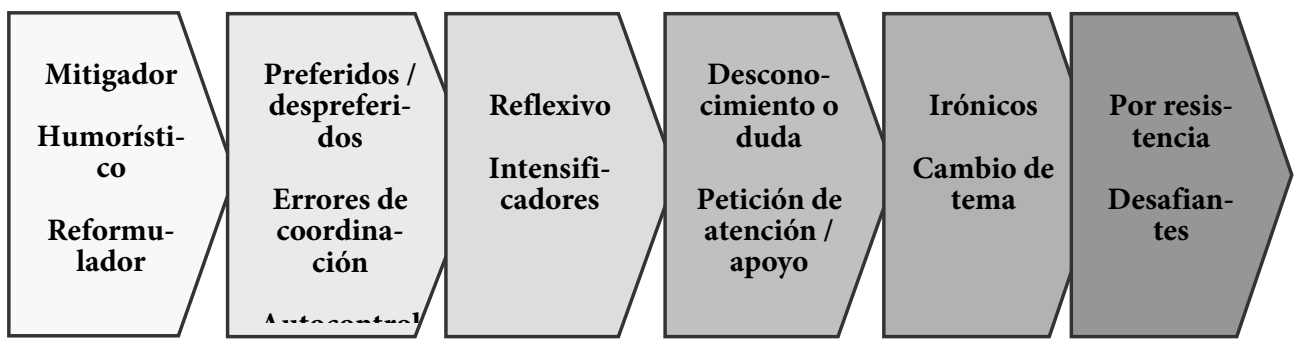

\section{Cortesía}

Descortesía

Figura 6. Tabla de niveles de (des)cortesía según la duración y las funciones de los actos silenciosos

\section{Anticortesía y silencio}

En la lengua/cultura española, como se ha dicho, el silencio conversacional siempre tiene un valor comunicativo concreto (mitigar, enmascarar, ironizar, reflexionar, afirmar, desafiar...), pero no ocurre lo mismo con su valor social, el cual está determinado por los condicionamientos contextuales (Brenes, 2009) y por la relación social de los participantes (Camargo y Méndez, en prensa). Tal y como apuntó Zimmermann (2003: 48), entre los jóvenes existen actos que estructural y funcionalmente se pueden caracterizar como contrarios a los actos corteses descritos en la teoría de la cortesía, ya que no quieren evitar la amenaza potencial de ciertos actos de habla y no quieren decir algo positivo sobre el interlocutor; se trata de los actos anticorteses, que aunque amenazan la identidad del otro, no desembocan en una ofensa hacia el interlocutor y no representan descortesía, sino una actividad antinormativa (Zimmermann, 2003: 57) o una estrategia comunicativa propia de una comunidad de práctica determinada.

Val.Es.Co no superan el segundo de duración (recordemos que en nuestro análisis ascendían a 393 más del $60 \%$ del total de los 662 de la muestra); ello nos lleva a pensar que los silencios largos son minoritarios entre los jóvenes españoles. En segundo lugar, los silencios por reformulación, autocontrol, mitigación e humor son más breves (con una duración media de entre 1,1s. y 1,3s.) que los actos silenciosos por petición de atención, petición de apoyo, cambio de tema (que oscilan entre 1,8s. y 3,3s. de media), a los que asignábamos un valor más alto de descortesía. Y, por último, y basándonos en la clasificación coste-beneficio que presentamos en este trabajo (Escandell, 2006), en los casos de Val.Es.Co se asocian costes más altos para el receptor en los silencios de petición (atención y apoyo) y cambio de tema que en aquellos que reformulan, mitigan, humorizan o intensifican el mensaje, cuestión que también coincide con los resultados de nuestro estudio. 
Partimos de esta idea de Zimmermann $(2003,2005)$ al considerar que en contextos en los que la relación de familiaridad y el grado de confianza entre los hablantes es muy alto, los silencios responden más a parámetros relacionados con la anticortesía que con actos de habla descorteses, por lo que puede afirmarse que no tienen la intencionalidad de dañar la imagen del interlocutor. En la comunidad de hablantes analizada (jóvenes universitarios españoles con lazos de confianza y amistad estrechos), se emplean recursos tal vez "inesperados" en otros grupos de hablantes, como el silencio, al que ellos recurren sin una intencionalidad descortés. Para este grupo de hablantes no es más que un mecanismo propio de su estilo comunicativo. La clave para esto puede estar en la existencia de una relación de amistad muy grande. Estos comportamientos aparentemente descorteses responden, como decimos, a una estrategia conversacional propia del grupo que causa un efecto social concreto: crear afiliación y cercanía entre el grupo y sus participantes. Consideramos que entre hablantes con una relación social tan estrecha y en conversaciones prototípicas coloquiales como las recogidas, los silencios no están funcionando como FTAs, esto es, como actos de amenaza de la imagen del interlocutor al que van dirigidos. El contexto espontáneo y la relación social de familiaridad son los que posibilitan que estos actos que han sido considerados por la tradición sociopragmática descorteses funcionen de manera diferente en estos intercambios comunicativos. En palabras de Bernal (2007: 77), lo descrito aquí serían "comportamientos de descortesía no auténtica con efectos interpersonales positivos". Coincidimos con la autora cuando afirma que más que actos "antinormativos" hacia el estilo comunicativo propio de los adultos y que se emplean con la finalidad de "atacar el sistema", son comportamientos que se dan entre jóvenes en un clima de confianza y alta cercanía interpersonal y en contextos informales y espontáneos. Entre nuestros informantes, por tanto, el silencio actúa como un mecanismo que, dentro de las normas de su grupo, ni amenaza ni daña la imagen, los caracteriza e identifica además de distanciarlos de otros grupos, reforzando sus relaciones, creando afiliaciones y generando complicidades ${ }^{13}$. Por ello, antes de asignar grados o niveles de (des)cortesía al silencio o a cualquier otro fenómeno discursivo, se deberá tener en cuenta quién lo produce, quién lo recibe y

\footnotetext{
${ }^{13}$ En futuros trabajos deberá realizarse un estudio comparativo entre este grupo de hablantes jóvenes universitarios con otros que atiendan a otras variables (distinta edad, sexo, nivel de instrucción...) para determinar hasta qué punto estos resultados, que actualmente vinculamos únicamente a hablantes jóvenes universitarios, son extrapolables o otros grupos de habla o comunidades de práctica que también tengan una relación social muy próxima, pero que no sean ni tan jóvenes ni con estudios superiores.
} 
dónde tiene lugar dicho acto; solo de esta manera se podrán llevar a cabo estudios fiables en el plano conversacional.

La tesis que defendemos es que el silencio, recurso comunicativo poco frecuente en español, necesariamente causará un efecto social ${ }^{14}$ (Bravo, 1996: 13) en la relación entre los hablantes. Este efecto, que se conocerá a partir del acto perlocutivo ${ }^{15}$ que provoque la ausencia de habla en el oyente, deberá ser necesariamente tenido en cuenta y nos indicará si el acto silencioso ha causado daño alguno sobre el receptor o si ha sido interpretado por el este como una actividad normativa dentro del grupo, pertinente y sin efectos descorteses ${ }^{16}$. De esta manera, que un silencio sea (des)cortés o anticortés dependerá del efecto que cause sobre la relación social. Entre los hablantes analizados en este trabajo predominan los actos anticorteses sobre los descorteses, pues la finalidad de su uso es principalmente comunicativa y no suponen una amenaza para la imagen.

También podrían relacionarse estos actos con el "comportamiento diplomático" o politic behaviour (Watts, 1989) que Meier (1995) prefiere denominar appropriate behaviour (comportamiento apropiado) y que Kerbrat-Orecchioni (2004) -como se comentó en páginas anteriores- propone llamar acortesía. Estos fenómenos han sido definidos como "la ausencia normal de un marcador de cortesía" (Kerbrat-Orecchioni, 2004: 49) esperada para una determinada situación comunicativa y que es considerada como adecuada por los participantes en ese contexto concreto. Barros (2011) los califica como "comportamientos comunicativos no marcados" en el sentido de que son los exigidos

\footnotetext{
${ }^{14}$ Bravo (1996: 13) entiende por efecto social "las consecuencias ya positivas ya negativas, que una determinada actividad comunicativa pueda tener sobre el clima social imperante en la situación en el momento de su ocurrencia".

${ }^{15}$ El principal inconveniente de decir que son los actos perlocutivos o efectos sociales los que nos permitirán saber el valor sociopragmático que dan los oyentes al silencio, como ya apunta Brenes (2009: 149), es que "siempre quedará la duda acerca de si lo manifestado por los interactuantes proyecta el verdadero impacto que los fragmentos de la conversación efectuaron sobre ellos, ya que la acción evaluativa del receptor puede ser estratégica en dos sentidos. Por un lado, alguien puede sentirse afectado por una expresión descortés, pero, al mismo tiempo, no exteriorizar dicho sentimiento de agravio o, simplemente, fingir no sentirse injuriado para que, de esta manera, el emisor no alcance su objetivo (Arndt y Janney, 1987; Mills, 2005). Por otro, el receptor puede enfatizar su sentimiento de afrenta con la finalidad de denigrar la imagen del receptor, mostrando que no es una persona considerada hacia los demás". En el caso del silencio entre este grupo de hablantes este hecho no se producirá muy a menudo puesto que se sabe que en intercambios entre hablantes con un grado de proximidad y la relación social tan cercana no suelen ocultarse o enmascararse los sentimientos, ni existe tampoco una intención de denigrar la imagen del receptor.

${ }^{16}$ Bernal (1997: 86-87) propone que en aquellos "contenidos descorteses en potencia" se vislumbrará un efecto descortés cuando el receptor evidencie un rechazo, se muestre claramente en desacuerdo o, incluso, realice a su vez actividades de amenazas a la imagen del interlocutor.
} 
por la situación de habla entre esa comunidad de práctica, pues existen situaciones en las que no aparecen marcadores de cortesía, pero ello no indica que el acto sea descortés. Así pues, un mismo comportamiento podrá dar cuenta de categorías diferentes, según las normas propias de la sociedad (o en este caso comunidad de práctica) en que se produzcan. No ha de olvidarse que "lo discursivo se encuentra al servicio de lo social" (Briz, 2004: 68), por tanto, "la (des)cortesía no se encuentra codificada en el elemento lingüístico en sí mismo, sino que es un efecto social que surge de la confrontación del valor verbal [o no verbal] aportado por dicho elemento y las normas de comportamiento propias de una situación comunicativa" (Brenes, 2009: 116). Por consiguiente, si un silencio no crea ningún "efecto social" en un determinado grupo, no deberá ser considerado descortés, sino que podrá considerarse acortés. En cambio, si lo que ocurre es que el silencio es una estrategia discursiva propia del grupo de hablantes -que lo identifica y diferencia de otros grupos- pero que no tiene efectos (des)corteses, podrá considerarse como anticortés. En el momento en que el silencio tenga efectos negativos para la relación social, podríamos hablar ya de descortesía.

\section{Conclusiones}

El hablante de una lengua está provisto de recursos comunicativos que provienen de su entorno social y de sus experiencias comunicativas previas, los cuales parcialmente comparte con otras personas (grupo o comunidad de práctica). Estos recursos, entre los que se incluye el silencio, se ponen en marcha en la interacción y se proyectan en los significados emergentes de la misma, creando nuevas alternativas y distintas consideraciones en cuanto a la cortesía se refiere, siempre en función del contexto. La cortesía, considerada un fenómeno sociocultural, se confirma, se actualiza, se modifica o se revierte en la situación de interlocución real y concreta. Para el caso del silencio, la cortesía debe medirse en términos de duración y coste-beneficio.

A raíz de la noción de anticortesía acuñada por Zimmermann (2003), se ha argumentado que aquellos actos considerados tradicionalmente descorteses que no desembocan en una ofensa hacia el interlocutor deben dejar de considerarse como tales, puesto que en muchas ocasiones son meras estrategias comunicativas propias de una comunidad de práctica que actúan en favor del éxito comunicativo. Precisamente a esto responden, normalmente, los silencios en contextos en los que la relación de familiaridad y el grado de confianza entre los hablantes es muy alto. En conclusión, puede afirmarse que en un clima de intimidad donde se dan buenas relaciones entre los interlocutores, en principio, tendrá lugar una conversación sin tensiones en la que el silencio no resultará un elemento que dañe la imagen social (face) de los participantes, sino un compo- 
nente más de la interacción. Lo que realmente indicará si el silencio es un acto (des)cortés o anticortés será el acto perlocutivo que propicie en el destinatario, es decir, no será hasta después de conocer su reacción ante el acto que se acaba de producir cuando podrá asignarse un valor sociopragmático al acto silencioso. Lo anterior lleva a concluir que, al igual que toda unidad pragmática, el silencio es altamente contextodependiente.

Por último, aunque aquí no se han podido abordar estos aspectos, la quinésica y algunos elementos paralingüísticos frecuentemente acompañan al vacío de palabras y comunican contenidos en simbiosis con el silencio. Esta cuestión deberá sin duda tratarse en futuros estudios en los que se cuente con un corpus de análisis audiovisual, para así poder conocer en mayor detalle la relación que se establece entre dichos elementos y los parámetros de cortesía.

\section{Convenciones de transcripción}

- Solapamientos.

(:) Alargamientos.

(-) Truncamiento o sílaba cortada.

(i!) Tono animado.

(?) Pasajes inciertos en la grabación.

$(<$ risas $=$ especificación del emisor $>)$ Risas.

(“") Citas o fragmentos en estilo directo.

(/) Pausas mínimas, es decir, que no lleguen a 0 ‘5seg.

(//) Pausas de entre 0`5 y 1 seg.

(///2) Silencios de más de 1 seg. (se especificará su duración).

(///2) Para destacar el silencio objeto de análisis.

Recibido: $25-X-2012$

Aceptado: 26-VI-2013

\section{Referencias bibliográficas}

Albelda Marco, M. (2004): "Cortesía en diferentes situaciones comunicativas. La conversación coloquial y la entrevista sociológica semiformal.” En Bravo, D. y A. Briz (eds.): Pragmática sociocultural: estudios sobre el discurso de cortesía en español. Barcelona, Ariel, págs. 109-134. 
Alvarado Ortega, B. (2005): "La ironía y la cortesía: una aproximación desde sus efectos”, ELUA, 19, págs. 33-47.

Arndt, H. y R. Janney (1987): InterGrammar: Toward an integrative model of verbal, prosodic and kinesic choices in speech. Berlín, Mouton de Gruyter.

Barros García, M. J. (2011): La cortesía valorizadora en la conversación coloquial española: estudio pragmalingüistico. Granada, Universidad de Granada.

Bernal Linnersand, M. (2007): Categorización sociopragmática de la cortesía y de la descortesía: Un estudio de la conversación coloquial española. Estocolmo, Universidad de Estocolmo.

Bilmes, J. (1994): "Constituting silence: Life in the world of total meaning", Semiótica, 98, págs. 73-87.

Bravo, D. (1996): La risa en el regateo: Estudio sobre el estilo comunicativo de negociadores españoles y suecos. Estocolmo, Universidad de Estocolmo.

Bravo, D. (2003): "Actividades de cortesía, imagen social y contextos socioculturales: una introducción”. En Bravo, D. (ed.): Actas del I Coloquio del Programa EDICE. Estocolmo, Universidad de Estocolmo, págs. 98-108.

Bravo, D. (2004): “Tensión entre la universalidad y relatividad en las teorías de la cortesía”. En Bravo, D. y A. Briz (eds.): Pragmática sociocultural: estudios del discurso de cortesía en español. Barcelona, Ariel, págs. 15-33.

Bravo, D. (2010): "Pragmática socio-cultural. La configuración de la imagen social como premisa socio-cultural para la interpretación de actividades verbales y no verbales de imagen". En Orletti, F. y L. Mariottini (eds.): (Des)cortesía en español. Espacios teóricos y metodológicos para su estudio. Roma-Estocolmo, Universidad de Roma Tre-Universidad de Estocolmo, págs. 12-45.

Brenes Peña, M. E. (2009) La agresividad verbal y sus mecanismos de expresión en el español actual. Sevilla, Universidad de Sevilla.

Briz Gómez, A. (1995): La conversación coloquial (Materiales para su estudio). Valencia, Cuadernos de Filología de la Universidad de Valencia.

Briz Gómez, A. (2004): "Cortesía verbal codificada y cortesía verbal interpretada en la conversación”. En Bravo, D. y A. Briz (eds.): Pragmática sociocultural: estudios sobre el discurso de cortesía en español. Barcelona, Ariel, págs. 67-93.

Brown, P. y S. Levinson (1987): Politeness. Some universals in language usage. Cambridge, Cambridge University Press.

Camargo Fernández, L. (2006): "Cuestiones metodológicas de la investigación en pragmática: ¿¿de dónde proceden nuestros ejemplos?”. En Calzón, J. A. et al. (eds.): Orientaciones Metodológicas, Actas I Congreso internacional de filología hispánica: jóvenes investigadores. Oviedo, Universidad de Oviedo, págs. 81-92.

Camargo Fernández, L. (2009): "La metapragmática". En Ruiz Gurillo, L. y X. Padilla 
García (eds.): Dime cómo ironizas y te diré quién eres. Una aproximación pragmática a la ironía. Frankfurt, Peter Lang, págs. 89-107.

Camargo Fernández, L. y B. Méndez Guerrero (en prensa): "Los actos silenciosos en el habla de las jóvenes españolas. Estudio sociolingüístico”, LinRed.

Campos Prats, M. y M. Romera Ciria (2012): "Sobre el concepto de face y (des)cortesía en la cultura española". Comunicación presentada en el XLI Simposio SEL. Valencia, Universitat de València.

Cestero Mancera, A. M. (1999): Comunicación no verbal y enseñanza de lenguas extranjeras. Madrid, Arco/Libros.

Cestero Mancera, A. M .(2000): El intercambio de turnos de habla en la conversación. Alcalá de Henares, Servicio de Publicaciones de la Universidad de Alcalá.

Ephratt, M. (2008): “The functions of silence”, Journal of Pragmatics, 40, págs. 19091938.

Escandell Vidal, M. V. (2006): Introducción a la pragmática. Barcelona, Ariel.

Gallardo Pauls, B. (1993): "La transición entre turnos conversacionales: silencios, solapamientos e interrupciones", Contextos, 11, págs.189-220.

Gallardo Pauls, B. (1996): Análisis conversacional y pragmática del receptor. Valencia, Ediciones Episteme (colección sinapsis).

Goffman, E. (1967): “On Face-Work”. En Goffman, E. (ed.): Interaction Ritual. New York, Anchor Books, págs. 5-46.

Haverkate, H. (1994): La cortesía verbal. Estudio pragmalingüístico. Madrid, Editorial Gredos.

Jaworski, A. (1993): The power of silence. Social and pragmatic perspectives. Newbury Park, SAGE.

Jaworski, A. (1997): Silence. Interdisciplinary perspectives. Berlin-New York, Mouton de Gruyter.

Kaul de Marlangeon, S. (2008): "Tipología del comportamiento verbal descortés en español, en cortesía y conversación: de lo escrito a lo oral. En Briz, A. et al. (eds.): III Coloquio Internacional. Programa EDICE. Valencia: Universitat de València, págs. 254-266.

Kerbrat Orecchioni, C. (1992): Les interactions verbales. Paris, Armand Colin.

Kerbrat Orecchioni, C. (2004): “¿Es universal la cortesía?”. En Bravo, D. y A. Briz (eds.): Pragmática sociocultural: estudios sobre el discurso de cortesía en español. Barcelona, Ariel, págs. 39-54.

Kurzon, D. (1995): “The right of silence”, Journal of Pragmatics, 23, págs. 55-69.

Kurzon, D. (1997): Discourse of silence. Amsterdam, John Benjamins.

Kurzon, D. (2007): “Towards a typology of silence”, Journal of Pragmatics, 39, págs. 
1663-1688.

Lakoff, R. (1973): “The logic of politeness, or Minding your P's and Q's”, Proceedings of the Ninth Regional Meeting of the Chicago Linguistic Society, pp. 345-356.

Leech, G. (1983): Principles of pragmatics. London, Longman.

Leech, G. (1997): “Introducing Corpus Annotation”. En Garside, R., Leech, G. y T. McEnery (eds.): Corpus Annotation. London/New York, Longman, págs. 1-18.

Levinson, S. (2000): Presumptive meanings. Cambridge, MTT Press.

Martín Rojo, L. (2010): Constructing inequality in multilingual classrooms. New York, Mouton de Gruyter.

Mateu Serra, R. M. (2001): El lugar del silencio en la comunicación. Lleida, Universitat de Lleida.

Meier, A. J. (1995): “Passages of politeness”, Journal of Pragmatics, 24, págs. 381-392.

Mills, S. (2003): Gender and politeness. Londres, Cambridge University Press.

Mills, S. (2005): “Gender and impoliteness”, Journal of Politeness Research, 1 (2), págs. 263-280.

Nakane, I. (2005): "Negotiating silence and speech in the classroom", Multilingua, 24, págs. 75-100.

Nakane, I. (2007): Silence in the multicultural classroom: perspections and performance. Amsterdam, John Benjamins.

Nakane, I. (2010): “The role of silence in interpreted pólice interviews", Journal of Pragmatics, 43, págs. 2317-2330.

Padilla García, X. A. y B. Alvarado Ortega (2010): "Being polite through Irony". En Koike, D. A. y L. Rodríguez-Alfaro, (eds.): Dialogue in Spanish. Studies in functions and contexts. Amsterdam, John Benjamins, págs. 55-68.

Poyatos, F. (1994): La comunicación no verbal (vol. I: "Cultura, lenguaje y conversación”). Madrid, Istmo.

PRESEEA (2008): “Marcas y etiquetas mínimas obligatorias”, Versión 1.2. 31-01-2008. http://www.linguas.net/preseea. Acceso: 20-09-2012.

Sacks, H., Schegloff, E. A. y Jefferson, G. (1974): “A simplest systematics for the organization of turn-taking for conversation”, Language, 50, págs. 696-735.

Saville-Troike, M. (1985): "The place of silence in an integrated theory of communication”. En Tannen, D. y M. Saville-Troike (eds.) Perspectives on silence. Norwood, Alex Publishing Corporation, págs. 3-18.

Searle, J. (2001): Mente, lenguaje y sociedad. Madrid, Alianza.

Sifianou, M. (1997): “Silence and politeness". En Jaworsky, A. (ed.): Silence. Interdisciplinary perspectives. Berlin-New York: Mouton de Gruyter, págs: 63-84.

Vivas Márquez, J. (2011): El relativismo cultural del silencio. Una propuesta para el aula 
de ELE desde la pragmática intercultural. Salamanca, Universidad de Salamanca.

Watts, R. J. (1989): "Relevance and relational work: Linguistic politeness as politic behaviour”, Multilingua, 8, págs. 131-166.

Zimmermann, K. (2003): "Constitución de la identidad y anticortesía verbal entre jóvenes masculinos hablantes de español". Actas del Primer Coloquio del Programa EDICE. Estocolmo, Universidad de Estocolmo, págs. 47-59.

Zimmermann, K. (2005): “Construcción de la identidad y anticortesía verbal”. En Bravo, D. (ed.) Estudio de la (des)cortesía en español: categorías conceptuales y aplicaciones a corpora orales y escritos. Estocolmo, Programa EDICE, Universidad de Estocolmo, págs. 245-271. 